\title{
Dragons on the Jacobean stage
}

\author{
Shokhan Rasool Ahmed \\ English Department, University of Sulaimani, Sulaimani-Kurdistan, Iraq \\ Email address: \\ shokhan_rasul@yahoo.com
}

To cite this article:

Shokhan Rasool Ahmed. Dragons on the Jacobean Stage. International Journal of Literature and Arts. Vol. 2, No. 5, 2014, pp. $173-186$. doi: 10.11648/j.ijla.20140205.15

\begin{abstract}
This paper investigates a mixture of plays both Elizabethan (Marlowe's Doctor Faustus (1594) and Greene's Friar Bacon and Friar Bungay (1588-92)), and Jacobean (Barne's The Devil's Charter (1607) and Rowley's The Birth of Merlin (1622)). These plays stage supernatural entities such as male witches, magicians and dragons. What binds all these plays together is having dragon(s) controlled by a magician. It is important to investigate the stage directions of the dragons in making their exits and entrances, what role they have in the plays, and how they affect the character of the drama. This study examines some sorcerer plays with special concentration on the character of the sorcerers, looking at the kinds of rituals and magic they make. Marlowe's Doctor Faustus, Greene's Friar Bacon and Friar Bungay, Barnes's Alexander VI, and Rowley's Merlin are male magicians and, each has a different role, being assisted by spirits or devils. I will investigate their role in each play and how they relate to witchcraft.
\end{abstract}

Keywords: Marlowe's Doctor Faustus, Greene's Friar Bacon and Friar Bungay, Barnabe Barne's The Devil's Charter, Rowley's The Birth of Merlin

\section{Introduction}

Flying dragon was much in demand in the courtly festivals to convey the princely power in the sixteenth century. The dragons were usually ornamented as fabled and living monsters. These festivals were to construct national self-image, and were also influenced by the personality of the prince. The use of dragons in the festivals and exhibitions was to present princely power and authority Werrett notes that 'Festivals featured firework-packed dragons atop castles or emerging from caves; dragons figured as great monsters in battle with other creatures or, most commonly, as 'flying dragon', sailing through the air exploding with sparks'. ${ }^{1}$ In Medieval drama, the dragon is seen as a monster that should be killed by the knightly hero. On the $23^{\text {rd }}$ of April of each year, the English celebrated St. George's day: the legend of Saint George who slew a dragon. Since the fourteenth-century this day became the England's national day and St. George became England's patron saint. The dragon color is green which represents the spirit of spring and George is a cultivator of land by the Greeks. The dragon also appears on the national flag of

${ }^{1}$ Simon Werrett, Fireworks: Pyrotechnic Arts and Sciences in European History (Chicago and London: The University of Chicago Press, 2010), p. 16.
Wales, which is red, and was used in the coat of arms of Henry VII. Dragon on the Royal arms is intended to inspire action. All in all, dragon is used in the national occasions to demonstrate strong patriotic feelings. Early flying dragons were often figured with banners and sails flown in the air and attached to crackers or lanterns.

Dragons in each play offer a particular version of supernatural spectacle and work by the art of magic to assist the main characters to achieve their goals. I will argue that early modern devils were presented with regards to the violence they inflict on others. I will investigate the scene in the Doctor Faustus B text of 1616 of Faustus's cosmic flight and initial landing in Rome, when Mephistopheles (the Devil) appears as a fierce dragon, flying and spitting fire. Faustus sits on Mephistopheles as he pulls Faustus' chariot through the sky when he wants to learn the secret of astronomy. In Friar Bacon and Friar Bungay a dragon shoots fire and a spirit like a lion breaks a branch of a tree. However, Greene's dragon serves a different purpose from Marlowe's dragon: Greene's dragons represent the theme of nationalism whereas the theme of anti-Catholicism emerges through the use of the dragon by Marlowe.

In The Devil's Charter, in the scene when two devils ride upon a lion, a dragon is used by the King's Men for their 
royal patron James I on Candlemas night. The devils are used as a main weapon of intimidation by Alexander VI. Pope Alexander conjures up the devil (Astoreth) to assist him in his attempt to climb to power. Similarly, the examination of The Birth of Merlin will primarily concentrate on the scene of the two flying dragons, Red (which represents the Britons) and White (the Saxons). The dragons' fight ends with the Red dragon's supernatural victory over the Saxon. Again the theme of English nationalism and a strong feeling of patriotism, as in Friar Bacon and Friar Bungay, are foregrounded here. This study takes a chronological approach in order to establish a dramatic development of the sorcerer in three theatrical modes - the tragic (Doctor Faustus), the comic (Friar Bacon and Friar Bungay, and The Devils' Charter), and the tragicomic (The Birth of Merlin).

\section{Christopher Marlowe's Doctor Faustus}

Christopher Marlowe died at the age of twenty-nine and his Doctor Faustus is not known to have been performed before his death in 1593; the first recorded performance took place on $30^{\text {th }}$ September 1594. It was first entered in the Stationer's Register on 7 January $1601 .^{2}$ The first edition, the 'A text', was published in 1604 (reprinted in 1609 and 1611) and the very different ' $\mathrm{B}$ text' was published in 1616 (reprinted in 1619, 1620, \&c.). For many years, critics have referred to the 'A text' as a 'Bad Quarto' and the 'B text' as 'Good Quarto'. The so-called 'A-text' is shorter than the 'B-text'. Greg describes the 1616 'B-text' as 'better written', although he adds that 'it might perhaps be thought ineffective'. The 1604 'A-text' meanwhile is 'shorter and more theatrically forcible, but is inferior in style'. ${ }^{3}$ Greg believes that the 'A-text' 'represents a report from memory of the play as first acted in London, shortened and otherwise adapted to the needs of a touring company and the taste of an uncultivated audience'. Jump also agrees with Greg that the 1616 quarto 'seems to stem independently from a fuller and more authoritative manuscript'. 5 This view is not accepted by Bevington and Rasmussen however, who argue that the 'A-text' was 'set in type from an original authorial manuscript composed of interleaved scenes written by Marlowe and a collaborating playwright', and that the 'B-text' 'represents a version of the play which was extensively revised more than a decade after Marlowe's death'. ${ }^{6}$ Collaborative authorship was the

\footnotetext{
${ }^{2}$ Christopher Marlowe, Christopher Marlowe: Doctor Faustus, ed. by Roma Gill, $2^{\text {nd }}$ ed. (London: A \& C Black, 1989), pp. xii-xiii.

${ }^{3}$ Christopher Marlowe, Marlowe's Tragical History of the Life and Death of Doctor Faustus; a conjectural reconstruction, ed. by W. W. Greg (Oxford: Clarendon Press, 1950), p. vii.

${ }^{4}$ Christopher Marlowe, The Tragical History of the Life and Death of Doctor Faustus (The University of Michigan: Clarendon Press, 1950), p. v.

${ }^{5}$ Christopher Marlowe, Marlowe: Doctor Faustus, a Casebook, ed. by John Jump (London: MacMillan and Co Ltd, 1969), p. 149.

${ }^{6}$ Christopher Marlowe, Christopher Marlowe: Tamburlaine, parts I and II; Doctor Faustus, A- and B-texts; The Jew of Malta; Edward II, ed. by David
}

norm in early modern England and plays were revised in order to offer more in the way of theatrical spectacles and popular entertainment.

Similarly, Gill does not accept Greg's theory, arguing that the A-text is the more original and the new parts of B (III.I, 90 ff.; ii; IV.i-vi; vii, 3 ff.; V.ii, 1-23, 85-130; iii) are the 'adicyones' for which Henslowe paid four pounds to two of his hack writers, Birde and Rowley, in $1602 .^{7}$ 'Adicyones' means the additional material that was appended in the B text including the comic flight scene of Faustus. The additional materials require more elaborate staging, such as a balcony and a celestial throne. Evidence suggests that Samuel Rowley was Marlowe's collaborator, and after a decade both Rowley and William Birde wrote additional materials for the play. Halpern also concludes that Marlowe worked with a collaborator on Doctor Faustus. ${ }^{8}$ In terms of a theatrical perspective, Halpern argues that the Blackfriars theatre offered a better context for spectacle than did the Rose. ${ }^{9}$ This suggests that the 1616 ' $\mathrm{B}$ text' was based on the demand of people for more spectacular effects commonly associated with popular entertainment.

As one can say that plays about witches and magicians were very popular in early modern England, and Doctor Faustus was clearly highly lucrative for the Admiral's Men at the Rose playhouse in London and became one of the most reprinted of all Elizabethan plays. ${ }^{10}$ The source for this play is taken from the German Das Faustbuch book published in Frankfurt by Johann Spies in 1587 and was first translated into English by P. F. London in 1592, as The Historie of the Damnable Life and Deserved Death of Doctor John Faustus. ${ }^{11}$ The first known performance of Doctor Faustus was on $30^{\text {th }}$ September 1594 by the Lord Admiral's men. ${ }^{12}$ In Doctor Faustus, the scholar Faustus gives his soul to Lucifer in return for twenty-four years of knowledge of black arts and pleasure. The play is a mix of tragedy with comedy and slapstick. In the farcical scenes between Faustus and Mephistopheles against the Pope, they disrupt the Pope's banquet after they fly to Rome. Marlowe was aware that attacks on and ridicule of the Catholic

Bevington and Eric Rasmussen (Oxford and New York: Oxford University Press, 1998), p. xxvii.

${ }^{7}$ Christopher Marlowe, Christopher Marlowe: Doctor Faustus, ed. by Roma Gill (London: Ernest Benn Limited, 1965), p. xv. It is also recorded in Henslowe's Diary that William Birde and Samuel Rowley made revision and "adicyons" to the B-text, for which they were paid 4 pounds by the theatre impresario Philip Henslowe in 1602. Philip Henslowe, Henslowe's Diary, ed. by A. Foakes and R. t. Rickert (Cambridge: C. U. P., 1961), p. 206.

${ }^{8}$ Richard Halpern, 'Marlowe's Theatre of Night: "Doctor Faustus" and Capital' ELH, 71 (2004), 455-495 (p. 462).

${ }^{9}$ Ibid., p. 475.

${ }^{10}$ Christopher Marlowe, Christopher Marlowe: Dr Faustus, ed. by Roma Gill; revised with a new introduction by Rose King, $3^{\text {rd }}$ ed. (London: A \& C Black Publisher, 2008), p.vii.

${ }^{11}$ Ibid., p. xxiii

${ }^{12}$ Christopher Marlowe, Doctor Faustus: $A$ - and B-texts $(1604,1616) /$ Christopher Marlowe and his collaborator and revisers, ed. by David Bevington and Eric Rasmussen (Manchester: Manchester University Press, 1993), p. 48. 
Church were popular fodder for entertainment among the theatrical audiences of protestant England while also capturing anxieties about the threat posed by foreign Catholicism.

This paper explores the stage directions added for the Good Angel in scene thirteen in 'B text' which cannot be found in 'A text'. Several scholars have already presented the differences and likenesses between these texts. However, my study only focuses on the stage directions and the use of technology after the text was amended or changed. This study investigates the comic scenes associated with the riding in a fiery chariot. In his last appeal to Mephistopheles, Faustus says 'so high our dragons soared into the air/ That, looking down, the earth appeared to me' (III.i.70-71). Brockbank argues that Faustus 'touches the source material with a Simonian and Renaissance delight in flight and remoteness'. ${ }^{13}$ The flight scene reflected the demand of the Renaissance audience as flying magicians and witches were fashionable at that time. This is why most of the plays on witches and magicians, such as Doctor Faustus, have a supernatural scene in which the main character flies.

Magicians and witches were invariably condemned for their tricks and demonic acts. However, the use of supernatural power in magic can be good or evil. Clark writes that a 'magician' was 'someone who sought to ascend to acknowledge of these superior powers and then accentuate their normal workings by drawing them down artificially to produce wonderful effects'. ${ }^{14}$ Faustus as a magician attempts to obtain the secret of astronomy and wants to exceed his natural capacities with demonic help. The magician acquires knowledge from the evil angel or unclean spirit when he tries to reveal some hidden or secret things in nature. Hence, the works of nature or seeking for natural power are associated with bewitchment and the world of witchcraft. Faustus is presented to the audience as an embodiment of anti-Catholicism, someone who does not care about the religious customs and hierarchies of Rome. $\mathrm{He}$ is curious to achieve knowledge of magic and to attain limitless knowledge on black art.

Ornstein argues that Faustus' arrogance, vanity and indulgence in the cardinal sin of pride leads the reader to see that his 'fall' is 'neither a simple moral degradation nor a conventional seduction from conscience and belief'. ${ }^{15}$ However, it is rather a moral education and discovery during which he is not degraded but humanized. Faustus as a learned man enters into a compact with Satan, just as characters do with the common witches in other plays, in order to obtain power and the knowledge of secret things. The difference between Faustus and female witches is that Faustus, unlike female witches, as a magician does not

\footnotetext{
${ }^{13}$ Christopher Marlowe, Marlowe: Dr. Faustus, ed. by J. P. Brockbank (London: Edward Arnold, 1962), p. 49.

${ }^{14}$ Stuart Clark, Thinking with Demons: The Idea of Witchcraft in Early Modern Europe (New York: Oxford University Press, 1997), p. 217.

${ }^{15}$ Robert Ornstein, 'Marlowe and God: The Tragic Theology of Dr. Faustus', PMLA, 83 (1968), 1378-1385 (p. 1382).
}

inflict harm (maleficium) by magical means. He also does not practise ritual murder, cannibalism or sexual orgies like female witches do. However, similarly to the female witches, he does fly and ride on strange animals and makes a pact with the devil.

The flight scene offers an element of slapstick comedy to the play and makes a comical history out of Faustus' rebellion. By the end of the play, Faustus' life comes to an end and even though the play is called a tragedy, the audience is entertained by the supernatural flight of Faustus when he is pulled by dragons. By doing so, Ornestein argues that Marlowe shares with his admiring contemporaries, such as George Chapman, 'the disenchanted vision of the aspiring mind-the knowledge that the Comic Spirit hovers over the Icarian flight of the self-announced superman'. ${ }^{16}$ A trick is used during Faustus's flight in order to disguise the self and not be seen. After Bonvolio (a knight) and his friends try to avenge the humiliation done to them by Faustus, Faustus also depends on magic and asks his devils to hurt them and grow horns on their heads. Faustus also has the power to deceive the Pope and his clerics and make himself invisible through the plot device of a trick. Marlowe has used both magical trick and disguising information here in order to adhere to the tragicomic convention of the play.

\section{Stage Directions in Doctor Faustus}

Marlowe's stage directions in both the 'A text' and 'B text' are not very elaborate and clear, and, modern editors have tended to add stage directions to help the reader imagine how the play was staged at that time. For example, certain stage directions, such as those at V.ii.1-25, 85-130 〈Thunder. Enter Lucifer, Beelzebub, and Mephostophilis [above] $>^{17}$, and [Music while the throne descends $]^{18}$ are added by A. H. Bullen. ${ }^{19}$ There are two other stage directions which can be found in Bevington's and Rasmussen's edition in III.i.93-98 when the conversation occurs between Bruno and the Pope: [He kneels in front of the throne], and when the Pope ascends: [A flourish while he ascends]. ${ }^{20}$ Again such stage directions (V.ii.100) cannot be found in the A-text but it is certainly in the B-text: Music while the throne descends. ${ }^{21}$ The Old Man enters to

\footnotetext{
${ }^{16}$ Robert Ornestein, 'The Comic Synthesis in Doctor Faustus', ELH, 3 (1955), 165-172 (p. 172).

${ }^{17}$ Christopher Marlowe, Marlowe's Tragical History of the Life and Death of Doctor Faustus, p. 59.

${ }^{18}$ Ibid., p. 62.

${ }^{19} \mathrm{I}$ bid., p. vi.

${ }^{20}$ Christopher Marlowe, Christopher Marlowe: Tamburlaine, parts I and II; Doctor Faustus, A- and B-texts; The Jew of Malta ; Edward II, p. 211. See also Marlowe, Doctor Faustus: A- and B-texts $(1604,1616)$, ed. by David Bevington and Eric Rasmussen,p. 236.

${ }^{21}$ Christopher Marlowe, Christopher Marlowe: Doctor Faustus, 1604 and 1616 (Menston: Scolar Press, 1970), B-text. See also Marlowe, Christopher Marlowe Doctor Faustus, ed. by Roma Gill, $2^{\text {nd }}$ ed., p. 106. Christopher Marlowe, Marlowe: Doctor Faustus, ed. by Roma Gill, $3^{\text {rd }}$ ed. p. 125; Marlowe, Christopher Marlowe, ed. by David Bevington and Eric Rasmussen, p. 242; Marlowe, Doctor Faustus: A- and B-texts $(1604,1616)$, ed. by David
} 
persuade Faustus to repent and asks for God's mercy but Mephistopheles threatens Faustus to tear his body into pieces if he agrees. Faustus then blames Mephistopheles for his damnation. The Good and Evil Angels arrive as the stage direction shows that they descend and ascend through the throne. After ten lines the stage direction is [The throne ascends.]Exit [Good Angel]. Hell is discovered. ${ }^{22}$ Dr. Faustus, before his death, Harris argues, 'is shown the heavenly throne he might have occupied. ${ }^{23}$ It is obvious that the stage direction is from the 'heavens' and that the throne is drawn up again after the good Angel laments. The throne here evidently stands as a symbol for heaven ${ }^{24}$ : The Throne of the Blessed (V.ii.1945-1946). Furthermore, the throne must have been large enough to have more than one in bright costume: 'In younder throne, like those bright shining Saints' (V.ii.2013). After the Scholars leave Faustus (V.ii), Mephistopheles appears. However, it is not very clear whether Mephistopheles descends from the balcony or not: 'there is no direction to indicate it, but if not, Faustus must here become aware that he is being watched, and this seems unlikely'. ${ }^{25}$ To have music during the descent of the throne might hint at the slow operation of the lifting machine. Doctor Faustus was performed at the Rose, built in 1587 by Philip Henslowe. The public playhouses did not have the capability to make descents and ascents at that time. The evidence of Henslowe's diary suggests that the use of a throne in the 'heavens' was not installed until 1595: 'item pd for carpenters worke \& macking the throne in the heuenes the 4 of June $1595,{ }^{26}$ Wickham concludes that the A-text does not need permanent 'heavens' supported by pillars and no throne with winch mechanism to be lowered or raised. However, it could have been performed on a raised and removable stage platform. ${ }^{27}$ In terms of architectural reconstruction, Wickham also argues that 'the early play-houses were equipped with removable trestle-stages', and 'such stages would of themselves make floor-trap scenes an undesirable element within a play'. ${ }^{28}$ In terms of theatrical building, the A-text was performed in a playhouse where it had 'above' and pillars. However, the A-text does not require 'above' since no stage direction calls for 'above' or 'heaven'.

Stage directions in the B-text add extensive material and

Bevington and Eric Rasmussen, p. 281. Marlowe, Christopher Marlowe: Doctor Faustus, ed. by Roma Gill, p. 85.Christopher Marlowe, Christopher Marlowe: Doctor Faustus, ed. by Keith Walker (Edinburgh: Oliver \& Boyd, 1973), p. 77. Christopher Marlowe, Marlowe's Doctor Faustus 1604-1616: Parallel Texts, ed. by W. W. Greg (Oxford: Clarendon Press, 1950), p. 287.

${ }^{22}$ Marlowe, Christopher Marlowe: Tamburlaine, parts I and II; Doctor Faustus, A- and B-texts; The Jew of Malta; Edward II, p. 242; Marlowe, Doctor Faustus: $A$ - and B-texts $(1604,1616) / C h r i s t o p h e r$ Marlowe and his collaborator and revisers, p. 282. Marlowe, Christopher Marlowe: Doctor Faustus, ed. Roma Gill, p. 86.

${ }^{23}$ Harris, Night's Black Agents, p. 159.

${ }^{24}$ Marlowe, Marlowe's Doctor Faustus 1604-1616: Parallel Texts, p. 395.

${ }^{25}$ Ibid., p. 127.

${ }^{26}$ Foakes, Henslowe's Diary, p.7.

${ }^{27}$ Glynne Wickham, "'Exeunt to the Cave": Notes on the Staging of Marlowe's

Plays', The Tulane Drama Review, 8 (1964), 184-194 (p. 186).

${ }^{28}$ Ibid., p. 188. thereby the supernatural characters make use of new theatrical spaces, such as 'above'. In V.ii.1 the stage direction is 'Thunder. Enter Lucifer, Beelzebub, and Mephistopheles [above]'. ${ }^{29}$ '[Above]' is a modern editorial intervention. The B-text, in contrast to the A-text, calls for special effects and more exploitation of physical space. In the final scene of the B-text, 'a throne descends, presumably by means of machinery in the 'heavens', to tantalise Faustus with a glimpse of the indescribable bliss he has forfeited; he would have sat 'in yonder throne', the Good Angel tells him, whereas now 'The jaws of hell are open to receive thee' (V.ii.111-20)'. ${ }^{30}$ When the stage direction reads 'the throne descends', it suggests that the operation of the lifting machine is slow and is included in order for the reader to imagine the action. The additions that both Birde and Rowley, whom Henslowe paid for revisions of Doctor Faustus in 1602, made are music, thunder, the usage of 'above', descents from the 'heavens', and departures from several doors. In another scene in A text Faustus confronts the devils and claims his success over them, 'Hence, hell, for hence I fly unto my God' (V.i.115). ${ }^{31}$ This line suggests that a simple lifting technology might probably be used for his descent. The devil's position is in 'heavens' above and controls the world whereas Faustus's position is in 'hell' below.

The most impressive scene in Marlowe's Doctor Faustus is when dragons pull Faustus's chariot through the sky. In order to learn the secret of astronomy, Faustus travels through the heaven on a chariot pulled by dragons. A functional deus ex machina is, as a plot device, created through Faustus' eagerness in the study of astrology, by which his destiny is manipulated. Mephistopheles is the dragon by which Faustus travels to Rome. Mephistopheles appears as a fierce dragon, flying and spitting fire, to Faustus who loftily sits upon him. His travel takes him to Rome after he measures the coasts and kingdoms of the world. The original stage direction reads as follows:

\section{Enter a Deuill.}

(Doctor Faustus, 1616) $^{32}$

In modern editions, a Devil enters on stage in the shape of a dragon: 'Enter a Devil [Mephistophilis, in the shape of a] dragon' (I.iii.24). ${ }^{33}$ The word 'dragon' does not appear in the A-text as it does in the B-text. The 'dragon' in the 'B' text (I. iii. 246) might come out of the stage trapdoor which hints at a simple lifting technology. ${ }^{34}$ Faustus practises

\footnotetext{
${ }^{29}$ Marlowe, Christopher Marlowe, ed. by David Bevington and Eric Rasmussen, p. 239.

${ }^{30}$ Marlowe, Doctor Faustus: A- and B-texts $(1604,1616)$, ed. by David Bevington and Eric Rasmussen, p. 45.

31 Marlowe, Christopher Marlowe, ed. by David Bevington and Eric Rasmussen, p. 179.

${ }^{32}$ ChristopherMarlowe, The Tragicall History of the Life and Death of Doctor Faustus (London, 1616), no page number is given.

${ }^{33}$ Doctor Faustus, A- and B-texts, David Bevington and Eric Rasmussen, p. 194.

${ }^{34}$ See Leo Kirschbaum, 'Mephistophilis and the Lost "Dragon", Review of
} 
black magic, and through the power of hell, he commands Mephistopheles to transform himself into a dragon first and then as a friar:

Enter a Devil [Mephistopheles, in the shape of a] dragon I charge thee to return and change thy shape.

Thou art too ugly to attend on me.

Go, and return an old Franciscan friar;

That holy shape becomes a devil best.

Enter Devil [Mephistopheles]

I see there's virtue in my heavenly words.

Who would not be proficient in this art?

How pliant is this Mephistopheles,

Full of obedience and humility!

Such is the force of magic and my spells.

Enter Mephistopheles [dressed as a friar] (DR FAUSTUS B-TEXT I.iii.22-31) ${ }^{35}$

In the English Faustus book, chapter two, 'Faustus began againe to coniure the Spirite Mephostophiles in the name of the Prince of Diuels to appear in his likenesse: where at sodainly over his head hanged houering in the ayre a mighty Dragon'. ${ }^{36}$ And in chapter nineteen, Faustus asks Lucifer if Mephistopheles can change his shape from a dragon into a friar: 'wherevpon came a fierce Dragon, flying and spitting fire around about the house, and comming toward Lucifer, made reuerence, and then changed himself to the forme of a Frier, saying, Faustus what wilt thou? ${ }^{37}$ Many of the early modern playwrights used different beasts into their plays such as dragons, lions, and eagles which evoked the beliefs of that time.

The dragon scene shows the most enthusiastic Protestant feeling. Marlowe uses a dragon in the scenes set in Rome on stage in order to present the theme of anti-Catholicism. Marlowe ridicules aspects of Catholic religious practice when Faustus teases the Pope by snatching his food and drink. This shows that instead of exchanging theological ideas, the Pope of the Catholic Church cares more about things to please his bodily appetites. Marlowe satirizes the Pope and his court, as agents of the Catholic faith, by making Faustus and Mephistopheles play practical jokes on the Pope and his clerics while invisible. Faustus and Mephistopheles mock the excommunication ceremony, purgatory, and other Catholic religious rites:

MEPHISTOPHELES. Nay, I know not: we shall be cursed with bell,

book, and candle.

FAUSTUS. How? bell, book, and candle; candle, book, and

bell;

Forward and backward, to curse Faustus to hell.

English Studies, 21 (1945), 233-235 (p. 233)

${ }^{35}$ Marlowe, Christopher Marlowe: Tambulaine, Parts I and II, Doctor Faustus, A- and B-Texts, The Jew of Malta, Edward II, p. 194.

${ }^{36}$ Philip Mason Palmer, Robert Pattison More, and Robert T. More, Sources of the Faust Tradition ([]: Ardent Media, 1966), p. 138.

${ }^{37}$ Ibid., p. 165.
Anon you shall hear a hog grunt, a calf bleat, and an ass bray,

Because it is St. Peter's holy day

Enter all the FRIARS to sing the dirge (III. i. 907-913). ${ }^{38}$

The three items he mentions are used in the ritual of excommunication when someone is excommunicated from the Church: '(the bell is tolled, the Bible is closed, and the candle is extinguished)'. ${ }^{39}$ Faustus continues mocking the Pope and his clergy. He calls the Catholic clergy by the names of hog, calf and asses. This might also mean that Faustus as a male magician has a supernatural power to turn the Pope and his clergy into the named animals. Then the Friars enter and sing a dirge, a type of funeral song. Faustus starts questioning about the nature of hell and salvation when he is at the heart of Church's power, Rome. In short, Faustus appears as a Protestant magician in the play but the Pope and his clergy are seen as venial and power-hungry. Marlowe includes a good deal of satire of the Pope and his court in order to make them appear ridiculous.

The Doctor Faustus A-text was a tragedy but the addition of the flight scene set in Rome in the B-text pushes it in the direction of tragicomedy, and revisions after the Restoration brought out further its comic potential. William Mountfort's The Life and Death of Doctor Faustus was first performed at the Queens Theatre in Dorset Garden and revised with new songs and dances. This production was first published in 1697 and performed in March 1686. Mountfort made this play into a farce by adding some comic material between the acts and with the humorous appearances of Harlequin and Scaramouche. The same stage directions can be found in scene of Hell, before the clock strikes eleven: 'Throne of Heaven appears; [ascend]; Hell is discovered; [descends]'. ${ }^{40}$ Such stage directions cannot be found in the A-text but are certainly in the B-text. This Restoration adaptation is also tragicomedy, designed for a period in the late (1680-90s) when farce was more popular and more likely to be a hit with audiences compared to tragedy in the theatres. Mountfort made Doctor Faustus into farce for the contemporary audience since he had knowledge about the technical abilities of the Queen's theatre for staging magical effects. This production was again revived once when Mountfort was alive (1697) and again after his death in 1724 .

By locating the flying dragon stage direction in the play, the 'flying dragon' was one of the most popular fireworks among gunners, magicians and alchemists throughout the sixteenth century. Not only are dragons and fireworks used in Doctor Faustus but weapons as well:

Faustus strikes the door, and enter a Devil playing on a

\footnotetext{
${ }^{38}$ Christopher Marlowe, Christopher Marlowe: Doctor Faustus with the English Faust Book, Introduction and Notes, ed. by David Wootton (Cambridge: Hackett Publishing Company, 2005), p. 41.

${ }^{39}$ Ibid., p. 41.

${ }^{40}$ William Mountford, The Life and Death of Doctor Faustus (1697) (London: E. Whitelock, 1697), p. 25.
} 
drum, after him another bearing an ensign, and divers with weapons; Mephistopheles with fireworks. They set upon the Soldiers and drive them out. [Exit Faustus] (B- Text, IV. Ii.106) $)^{41}$

Shooting fire and fireworks were a significant spectacle of early modern theatre. By the middle of sixteenth century, fireworks became one of the most spectacular elements of political celebration and theatre. Fireworks had a remarkable fiery effect in theatre to create a new genre of spectacle in presenting princely power and martial values to the audience. Simple fireworks, Werrett argues, were also added 'to mystery plays and holy festivals at Christian religious sites, imitating the sound and appearance of celestial and meteoric scenes that mediated between heaven and earth'. ${ }^{42}$ The point here is fireworks would work in the open and roofed playhouses. The Globe theatre burned down in 1613 during a performance of Shakespeare's Henry VIII because of the sparks or wadding fell out of the cannon and ignited the roof of the theatre, firm evidence that fireworks were being used in the open air playhouses to create spectacular and curious effects.

Dragon-powered flight is not only narrated in Marlowe's Doctor Faustus B text but also in Greene's Friar Bacon and Friar Bungay, but for a different purpose. It seems that Marlowe imitated Greene since both plays have some similar themes and events. Greene's hero is different from Marlowe's as he is a guiltless and benevolent magician. Friar Bacon and Friar Bungay deals with white magic in contrast to the black magic of Doctor Faustus.

\section{Robert Greene's Friar Bacon and Friar Bungay}

The second play in this paper is concentrated on Robert Greene's Friar Bacon and Friar Bungay (1589) ${ }^{43}$, an Elizabethan play, especially the scene when a dragon shoots fire and a spirit like a lion breaks a branch off a tree. There was a great demand in 1588-9 for plays about magicians and spectacular tricks. People at that time were delighted in the dexterity of the supernatural mysteriousness of the magician and witches, and moreover there was a popular appetite for spectacles within such plays. Lavin argues that Friar Bacon and Friar Bungay is 'historically significant as the first successful Romantic comedy', and 'it is probably also the first English play in which a true double-plot (as opposed to a comic sub-plot) was employed. ${ }^{44}$ Greg assumes that Greene in writing his Friar Bacon and Friar Bungay followed Marlowe's Doctor Faustus. ${ }^{45}$ However,

\footnotetext{
${ }^{41}$ Marlowe, Christopher Marlowe, ed. by Bevington and Rasmussen, p. 227.

${ }^{42}$ Simon Werrett, Fireworks: Pyrotechnic Arts and Sciences in European History, p. 16.

${ }^{43}$ Robert Greene, Friar Bacon and Friar Bungay, ed. by J. A. Lavin (London: Ernest Benn Limited, 1969), p. xii.

${ }^{44}$ Ibid., p. xxi.

${ }^{45}$ Greg, Marlowe's Doctor Faustus: Parallel Text, pp. 7-8, 10. And Marlowe, Doctor Faustus: A- and B-texts, ed. by David Bevington and Eric Rasmussen, p. 1.
}

most critics agree that Marlowe followed Greene in writing Doctor Faustus and borrowed material from him. ${ }^{46}$ The general tone of patriotism in Friar Bacon and Friar Bungay suggests that the date of writing the play was after the victory of England over the Spanish Armanda in 1588, although there is no definite date when the play was written.

The play was first printed in 1594 and was entered by Edward White in the Stationers' Register on $14^{\text {th }}$ May of that year. ${ }^{47}$ It was first performed at the Rose theatre in 1592 by the Lord Strange's Men. There are three editions of Friar Bacon and Friar Bungay: the first one from 1594 (probably from Greene's fair or foul papers), ${ }^{48}$ the second edition of 1630, and the third of 1655. The Honorable History of Friar Bacon and Friar Bungay is one of four plays that Greene wrote wholly by himself and it is authenticated. ${ }^{49}$ Henslowe's Diary shows that the play was revived for the court with a new prologue and epilogue by Middleton:

Lent vnto Thomas downton the 14 of deseb3

1602 to paye vnto $\mathrm{m}^{\mathrm{r}}$ mydelton for a prologe \&

A epeloge for the playe of bacon for the corte

The some of............................. $\} \mathrm{V}^{\mathrm{s} 50}$

The plot is based on the thirteenth-century Franciscan Roger Bacon who was known as a magician by his community. Prince Edward, King Henry VIII's son, attempts to seduce Margaret with the magical help of Friar Bacon and his friend Earl Lacy. However, Lacy falls in love with Margaret himself. Bacon shows Edward the love between Lacy and Margaret through his magical glass. However, by the end of the play both couples are married, Edward to Elinor of Castile and Margaret to Lacy. In the presence of both the Kings of England and Castile, and the German Emperor, Bacon wins a magical competition with Vandermast. With the assistance of another magician, Friar Bungay, Bacon creates an artificial brazen head made of brass, animated by the art of magic, as a protective wall around England. Both Marlowe and Greene brought late academic anxieties of the Elizabethan era into the stage and could make use of the written texts as their sources: the German Das Faustbuch and anonymous chapbook The Famous Storie of Fryer Bacon. Nonetheless, it took an inventive technique to translate these textual materials onto the commercial stage.

In terms of stage spectacle and theatrical effect, the scene when Bungay raises the golden apple-tree of the Hesperides

\footnotetext{
${ }^{46}$ Robert Greene, Friar Bacon and Friar Bungay, ed. by Daniel Sletzer (London: Edward Arnold, 1964), p. ix.

${ }^{47}$ Robert Greene, Friar Bacon and Friar Bungay ([Menston]: Scolar Press, 1973), p. introduction note.

${ }^{48}$ Greene, Friar Bacon and Friar Bungay, ed. by Lavin, p. xxxiii.

${ }^{49}$ Robert Greene, The Life and Complete Works in Prose and Verse of Robert Greene, ed. by Alexandre B. Grosart, 15 vols (New York: Russell \& Russell, 1964), xiii, p. vii.

${ }^{50}$ Henslowe's Diary, p. 207. Robert Greene, The dramatic and poetical works of Robert Greene \& George Peele: with memoirs of the authors and notes, ed. by Alexander Dyce (London: Routledge, 1861), p. 32.
} 
guarded by a dragon shooting fire is dramatically impressive. Then Hercules appears in his lion's skin to take off the branches of the tree. In the first round, Vandermast defeats Friar Bungay: while Friar Bungay conjures up the tree and Hercules, a spirit is conjured up by Vandermast, which breaks the branches of the tree. In the second round however, Bacon defeats Vandermast and commands the spirit to transport Vandermast back to Germany. The stage direction of this scene in all the editions is the same:

Here Bungay conjures, and the tree appears with the dragon shooting fire (ix.83). ${ }^{51}$

Lavin argues that 'one of the trap doors in the stage was probably used for this effect ${ }^{, 52}$ as Vandermast says 'Raised Hercules to ruinate that tree/ that Bungay mounted by his magic spells' (ix. 132). Lavin means that the trap door from downstage was used to stage this scene. ${ }^{53}$ Seltzer also confirms that the scene when Bungay conjures the apple tree and dragon might have been performed over the trap door, on the main apron. ${ }^{54}$ This play was performed at the Rose in 1592 and the public playhouses did not have the capacity to make descents and ascents at that time. One can be sure that a trap door was used in staging this scene. The historical dragon is used here to incorporate the theme of English nationalism. Simpson lists four general theories which are commonly proposed to account for dragon legends: 'naturalistic' (arising from fossil finds, or from encounters with real but exotic beasts); 'mythological' (symbolizing chaos, destructive floods, or evil forces preventing access to life-giving waters); 'religious' (with particular stress on the Devil/Dragon identification in Christian iconography); 'historical' (the dragon as emblem of enemies using dragon-figures as battle-standards or ships' figureheads) ${ }^{, 55}$ In this play the dragon is used as an emblem of enemies as the play portrays the war of 1588 between England and Spain which ended with the victory of the English. One of the most widespread themes in legend and Elizabethan stage is the dragon-fight. McNeir argues that 'the patriotic attitude of Friar Bacon is continued and extended in the sequel, in which the English magician-hero overcomes the foreign forces of evil of whom he is marched on their own soil'. ${ }^{56}$ Most of the events in the play relate to Bacon's magical powers as he plans to protect England and avoids his humiliation of the German emperor, Vandermast. Friar Bacon has pride in

\footnotetext{
${ }^{51}$ Greene, Friar Bacon and Friar Bungay, ed. by Sletzer, p. 56. Robert Greene, Friar Bacon and Friar Bungay ([Menston]: Scolar Press, 1973); Robert Greene, The Life and Complete Works in Prose and Verse of Robert Greene, ed. by Grosart, p.59; Greene, The dramatic and poetical works of Robert Greene \& George Peele, p. 167; Greene, Friar Bacon and Friar Bungay, ed. by Lavin, p. 56.

${ }^{52}$ Greene, Friar Bacon and Friar Bungay, ed. by Lavin, p. 56.

${ }^{53}$ Ibid., p. Xx.

${ }^{54}$ Greene, Friar Bacon and Friar Bungay, ed. Daniel Sletzer, p. 99.

${ }^{55}$ Jacqueline Simpson, 'Fifty British Dragon Tales: An Analysis', Folklore, 83 (1978), 79-93 (p. 83).

${ }^{56}$ Waldo F. McNeir, 'Robert Greene and John of Bordeaux', PMLA, 64 (1949), 781-801 (p. 800).
}

England and expresses a nationalistic motivation when Dr. Mason asks him to reveal his art:

... I will strengthen England by my skill,

That if ten Caesars liv'd and reign'd in Rome,

With all the legions Europe doth containe,

They should not touch a grass of English ground.

The work that Ninus rear'd at Babylon,

The brazen walls fram'd by Semiramis,

Carved out like to the portal of the sun,

Shall not be such as rings the English strond

From Dover to the market place of Rye. (ii. 57-65) ${ }^{57}$

Bacon's motivation is to defend England by making a protective wall around through his magical power in order to keep it from invaders, namely the Spanish Armanda. Friar Bacon also assists Prince Edward with his love problem. Thus, the sorcerer Friar Bacon here through his magic, as functional deus ex machina, manipulates the events of the play and solves the problem of the play.

Similar to Doctor Faustus, Bacon is also seeking to escape damnation. Edd Winfield Parks and Richmond Croom Beatt interpret Friar Bacon and Friar Bungay as:

written to compete with Marlowe's highly successful $D r$. Faustus. But the two plays are radically different, for Greene's comedy has only one tragic incident, and deals with "white" or harmless magic which may be indulged in without spiritual damnation, in contrast with the black magic of the tragic Faustus. ${ }^{58}$

Friar Bacon does not, like Doctor Faustus, lose his soul, for he has not made an express compact with the devil. ${ }^{59}$ Faustus cannot repent and he sees Christ's blood running in the sky on his last night. According to Christian belief, this blood stands for the sacrifice that Jesus made on the cross to open the path for humankind to repent their sins. However, Faustus fails to repent and even Christ's blood does not take him to salvation. By contrast, Friar Bacon repents and he does not need to see Christ's blood, 'it repents me sore/ That ever Bacon meddled in this art'. His realization makes him repent and he tells himself, 'end all thy magic and thin art at once'.

Knight argues that Friar Bacon refers to 'contemporary institutional preoccupations, but usually, rather than concentrating on institutions like the court, legal system, or church, Greene's concerns are for educational institutions' ${ }^{60}$ Friar Bacon and Friar Bungay does not only represent court power, but also the academic expertise of Greene himself during a royal visit to Oxford. He also

\footnotetext{
57 Robert Greene, Friar Bacon and Friar Bungay, ed. Daniel Sletzer (University of Nebraska Press, 1963), p. 13.

${ }^{58}$ Quoted in Frank Towne, 'White Magic' in Friar Bacon and Friar Bungay?', Modern Language Notes, 67 (1952), 9-13 (p. 9.)

${ }^{59}$ Ibid., p. 11.

${ }^{60}$ Sarah Knight, 'The Niniversity at The Bankside: Robert Greene's Friar Bacon and Friar Bungay', in The Oxford Handbook of Tudor Drama, ed. by Betteridge and Walker (Oxford: Oxford University Press, 2012), pp. 355-370 (p. 356).
} 
interweaves his academic experience and English nationalism together. The satire here is in the dispute scenes between the Oxford friars, Bacon and Bungay, and the German Vandermast, especially during the appearance of a dragon shooting fire, the spirit of Hercules in a lion skin breaks a branch of the tree and, finally when Vandermast carried away on a tree. By representing this occasion at the Rose theatre, 'Greene brings the Niniversity en fete to the Bankside,' and 'irrelevantly showing that scholarly and royal dignity can always be undermined and interrupted' ${ }^{61}$ Greene presents his philosophical experience for the royal visit of Elizabeth I which offers a spectacular spectacle to the Bankside audience.

In contrast to the lengthy dialogue between the two friars, which has the potential to make the play static in feel, Greene uses the fire-breathing dragon to entertain the spectators through spectacular, colourful special effects. Dragons are physically manifested differently on Elizabethan stage compared to Medieval and Jacobean stages. John Dee (1527-1609) was the first person to design a clever stage-effect for Greek drama, Aristophanes' Peace, and made a giant beetle that could move from the air down to the stage. Tygaeus rides on the back of a giant dung beetle to the heaven in order to arrange peace for the Greeks. However, Marlowe and Greene's dragon is different from Dee's: Marlowe's dragon is Mephistopheles in devil's dress, and Greene's dragon is in models. This kind of costume allows the play to be more tight and lively. Their dragon enters and exits the stage through a trapdoor which demonstrates that the ability of the theatres to stage these technically-demanding scenes had improved by the 1580 s.

\section{Barnabe Barnes's The Devil's Charter}

Like the previously discussed playwrights, Barnes in his The Devil's Charter (1607) also includes a most effective scene in which two devils ride upon a lion, or dragon. We learn from the title-page that the play is 'The Devil's Charter: A tragedy Containing the Life and Death of Pope Alexander the six. As it was plaide before the kings Maiejestie, vpon Candlemasse night last by his Maiejesties Seruants. But more exactly renewed, corrected and augmented since by the Author, for the pleasure and prays of the Reader'. ${ }^{62}$ Candlemas night refers to 'the date in the Church calendar devoted to warding off the powers of darkness through Christ, the light of the world - an appropriate date for the play's royal command performance'. ${ }^{63}$ In contrast to the plays already discussed in

\footnotetext{
${ }^{61}$ Ibid., p. 359.

${ }^{62}$ Barnabe Barnes, The Devil's Charter: A tragedy Containing the Life and Death of Pope Alexander the six. As it was plaide before the kings Maiejestie, vpon Candlemasse night last by his Maiejesties Seruants. But more exactly renewed, corrected and augmented since by the Author, for the pleasure and prays of the Reader, $\mathrm{p}$. title page.

${ }^{63}$ Barnabe Barnes, The Devil's Charter, ed. by Nick Hern (London: International Shakespeare Globe Centre, 1999), p. Vii.
}

this thesis, Barnes uses the effect of dragons and devils for different purposes. They are used as a means of intimidation and represent the lust for power. The play is about Pope Alexander VI (1492-1503) in general and it also concentrates on the social dynamic of devils on the Jacobean stage. The play was entered in the Stationers' Register in October 1607 and was printed by 'G. E.' for John Wright. It was performed in 1606 by the King's Men at Court and was first published in 1607. Barnes borrowed the history of the Borgias from Guicciardini for his play using the English translation rather than the original Italian text. However, some of the incidents of the play are not found in Guicciardini as they are only the invention of Barnes himself, such as Lucretia's marriage with Francesco di Gonzaga, the murder of Gismond di Viselli by Lucretia and her own death at the hands of Alexander.

The Devil's Charter and Shakespeare's Macbeth are two plays that the King's Men staged in 1606-1607 in which they pay great attention to stage devilry. The play exploits contemporary anxieties in response to the event of the Gunpowder Plot (1605) and the accession of King James I who, as has already been discussed, published his Daemonologie some years earlier in 1597. After the accession of King James I, the King's Men staged plays which had themes of diabolism and witchcraft in order to take advantage of the monarch's deep personal interest in such subjects. Barnes uses the Devil as a response to old traditional beliefs associating the Devil with attributes of ambition and tyranny, such as we also find in Macbeth. Pope Alexander VI conjures up Astoreth to assist him in his climb to power.

In this play, Barnes investigates and anatomizes the role of intimidation in a variety of human relationships, both personal and political. For instance, there is sexual intimidation involving the character of Lucrezia Borgia (Alexander's daughter). In order to control her husband, Lucrezia uses sex and social class to destroy Gismond di Viselli; Lucrezia stabs him and pretends his death was suicide after forcing him to sign a note. Gismond is not the only victim of her sexual rapacity: so are both princes Astro and Philippo, the Manfredi brothers. Cox argues that 'Barnes depicts Alexander as almost unsurpassed in intimidating strategies, both offensive and defensive'. ${ }^{64}$ Alexander devotes himself to his children but at the same time he uses them as an instrument of policy in his own interest to improve his power. In order to defeat his rivals, Alexander thinks about making an alliance with them. The devils have relationships with individuals and lead them into intimidation. Thus, the devils are here used as a main weapon of intimidation by Alexander to defeat the Pope. The devils are used with demonic intimidation when Alexander poisons Baglioni (the devil poisons Alexander in the same way Alexander does to Baglioni). The devil kills Alexander by switching the glasses, and Alexander drinks

\footnotetext{
${ }^{64}$ John D. Cox, 'Stage Devilry in Two King's Men Plays of 1606', Modern Language Review, 93 (1998), 934-947 (p. 938).
} 
the poisoned wine which was prepared by himself for the Cardinals.

The Devil in these plays is a major character. Barnes has two demons, Astaroth and Belchar: the first one is in the shape of a Pope and the second one is referred to as Protonotary. As we have seen, Marlowe also puts the Pope on stage in B text (III.i.26-27, 52, 64, 77). However, the Pope does not have power over Faustus and Mephistopheles. In The Devil's Charter, the term of the agreement between Alexander and the Devil is for two years and eight days. Through the signing of the contract with the Devil as the usual exchange, Alexander gets power and obtains the Papacy.

Regarding the entrance of Barnes's devils, before Rodrigo Borgia sits on a chair, a Monk conjures a dumbshow. Through a series of magical incantations, such as lightning and smoke, a 'devil in most ugly shape' appears whom Rodrigo does not like and whom he banishes because of his hideous form. Another devil has been conjured out of fire and brim-stone but Rodrigo still does not like him and he descends back. In the mist of thunder and fearful fire, another two devils with acceptable shape appear dressed in pontifical robes (they have the shape of human beings, such as Pope and protonotary) ascend and later descend:

A diuil in most vgly shape: from which Roderigo turneth his face, hee being coniured downe after more thunder and fire, ascends another diuill like a Sargeant with a mace vnder his girdle: Roderigod is liketh. Hee discendeth: after more thunder and fearefull fire, ascend in robes pontificall with a triple Crowne on his head, and Crosse keyes in his hand: a diuill him ensuing in blacke robes-like a pronotary, a cornerd Cappe on his head, a box of Lancets at his girdle, a little peece of fine parchment in his hand. ${ }^{65}$

With respect to costume and props, Barnes also offers his audience a different type of devil from those offered by Greene and Marlowe. Barnes describes in detail his devils and which properties they have in their hands on stage. Alexander makes a pact with the Devil to obtain the power. The difference of their pact with the devil is that no blood is lanced out of Doctor Faustus's arm by the Devil whereas Alexander's blood is lanced out by the devil and his blood fills a bowl. Then the first devil drinks the blood, reflecting an aspect of Continental witchcraft belief. Witches were believed to give her blood to her familiar in order to maintain the pact made between them. ${ }^{66}$

Alexander conjures up the devil (dressed as a king) with a red face who is riding on a lion, or dragon. There is a spectacle of thunder and lightning again accompanied with the devil's entrance. The stage directions read:

\footnotetext{
${ }^{65}$ Barnes, The Devil's Charter, no page number is given.

${ }^{66}$ For details see Barbara Rosen, Witchcraft in England, 1558-1618 (New York: University of Massachusetts Press, 1991), p. 19.
}

Fiery exhalations lightning thunder ascend a King, with a red face crowned imperiall riding vpon a Lyon, or dragon: Alexander putteth on more perfume and saith. $(\text { IV.i })^{67}$

This supernatural scene is rich in stage spectacle and its elaborate stage direction gives the Kings' Men some leeway in special effects. Alexander asks to find the one who has murdered his son Candie. The devil disappears and a few lines later another devil descends with thunder and lightning dressed in a suit of armour:

The diuell descendeth with thunder and lighning and after more exhalations ascends another all in armor. (IV.i) ${ }^{68}$

It may be presumed that a trap-door was used to stage the entrances and exits of the devils, since the play was performed at Court in 1606-1607, and the Court theatre did not have any flying machinery for staging the supernatural effects at that time.

The devils here are used as a dramatic device in Barnes's dramatizing of the lust for power, a theme which can also be found in Macbeth and Doctor Faustus. The pact which Faustus makes granting him special power and knowledge, requires him to submit to the Devil. Thus, Barnes, Shakespeare and Marlowe portray demonic involvement with human beings and how devils are intimately identified with the human lust for power. Shakespeare's use of devils on stage is more marginal though than that of Barnes and Marlowe. However, in all the plays mentioned above, the devil scenes motivate the plot by providing opportunities for sensationalism.

Barnes' use of intimidation in relation to the character of Lucretia is similar to Lady Macbeth of Macbeth. Lady Macbeth is an example of a malevolent mother when she calls to her demons 'come to my woman's breasts/ And take my milk for gall' (I.v.46-47). Denying her femininity, Lady Macbeth tries to conjure up evil spirits, and her diabolic malevolence motivates the plot in the murder of Duncan. In Macbeth the witches do not overpower Macbeth but only prophesy to him. However, the devils here overpower Alexander. Alexander uses the devils as a means of intimidation to defeat the Pope. Furthermore, Macbeth's witches are not a model of intimidation in relationships, but they work as an agent to destroy Macbeth. So, one can say that Barnes is inspired by Shakespeare's Macbeth in writing The Devil's Charter but Macbeth is a more traditional play than Barnes's. However, both plays are indebted to Marlowe's Doctor Faustus as both protagonists, Macbeth and Alexander; of the plays depend on demonic assistance to aid them in climb into power.

The King's Men performed The Devil's Charter for their royal patron James I. I mentioned earlier that dragons had been used in the Elizabethan stage for the royal festivals

\footnotetext{
${ }^{67}$ Barnes, The Devil's Charter, no page number is given

${ }^{68}$ Ibid., no page number is given.
} 
and exhibitions in order to present princely power and authority (see pp.176-177). In Christianity, the dragon is a symbol of evil and is associated with Satan. Dragons and devils in the shape of armour are used as powerful creatures to guard a country. In addition, the use of dragons, animated by magical art, in connection with political agitation, is used to control the social and religious pressures. In all the plays of this chapter, the dragons are under complete human control by which they gain their knowledge, power, and wisdom.

\section{William Rowley's The Birth of Merlin}

The fourth play to be examined in this paper is The Birth of Merlin by William Rowley (1622), a play very rich in visual spectacle. Rowley includes varied types of visual effects, such as, disguising, magic and the spectacle of devils. This examination primarily concentrates on the scene of the two flying dragons and the magician Merlin.

The play begins with the story of Modestia (the daughter to the nobleman Donobert and sister to Constantia). Modestia is conflicted between her desire for a religious vocation and the social pressure she is put under to marry. In the second scene King Aurelius and his royal court are introduced to the audience. The British are excited by their victory over the Saxon. The King's brother Uter is missing and a Saxon representative is sent to attend court and to attempt reconciliation. The court is led by a Saxon princess (Artesia), with whom king Aurelius falls in love. In Act two, the Clown and his pregnant sister, Joan, are introduced. The Clown and Joan are searching for the father of the child (Merlin) in the forest. Prince Uter is also seen wandering in the forest. The Clown takes him as a potential husband for Joan. Aurelius and Artesia get married and Uter finds out Artesia is his sister-in-law and the new British Queen. Joan encounters her actual husband, who is in fact the Devil. The Devil calls Lucina and the Fates to look after Joan as she gives birth to Merlin, the Magician. Merlin, Joan and the Clown visit the place where King Vortigem (King of Britain) is building a castle. In order to avoid continual collapse, the Welsh must sacrifice a 'fiend begotten child'. Therefore, Merlin's visit to Wales makes them feel pleased and relieved. Merlin predicts Vortigem's defeat at the hand of Edol (Earl of Chester, and General to King Aurelius) and the British. The battle of the dragons, White and Red, occurs which portrays Edol's victory. Merlin prophecies on a blazing star which is one of the most spectacular effects of the play. Finally, the British defeat the Saxons, Aurelius dies and Uter becomes the British King and Merlin, and is aided by Merlin.

The date of this play's composition is unclear. However, Dominik suggests that The Birth of Merlin was written in $1613-1615^{69}$, as 'the period $1613-15$ as the most likely chronological interval for Shakespeare's and Rowley's

\footnotetext{
${ }^{69}$ Mark Dominik, William Shakespeare and The Birth of Merlin (Oregon Alioth Press, 1991), p. 39.
}

authorship of The Birth of Merlin, with special emphasis on 1615 as the most probable single year'. ${ }^{70}$ The joke about 'Great Britains' (III.i.60) in which the Clown alludes to his own girth, has been considered to indicate a date after 1604 when James I proclaimed the union of England and Scotland under the title of 'grete Brytayne'. ${ }^{71}$ Brooke argues that 'from the language and grammar ... it is clear that The Birth of Merlin was not composed later than the reign of James I; nor is it at all likely that it antedates James's succession'. ${ }^{72}$ The first known performance of this play was in 1622 at the Curtain theatre and it was published in a quarto in 1662, printed by Thomas Johnson for Francis Kirkman, and Henry Marsh. Despite the fact that the play is colourful and entertaining, it has not received much attention by scholars. Not only are devils and magic employed as spectacles in the play, but there is also the scene of the blazing star, which is one of the most elaborate special effects so far in any of the plays discussed here. Edol's victory is portrayed through a series of battles, culminating in a blazing star scene on which Merlin prophesizes. The blazing star has a dragon's head inside it with two flaming flakes emanating from its mouth. Merlin prophesizes that the dragon's head represents Uter, and the two flaming flakes of fire to east and west, his son and daughter. The stage direction reads:

\section{'Blazing Star appears'. PRINCE look Edol: \\ Still this fiery exhalation shoots \\ His frightful horrors on th' amazed world, \\ See in the beam above his flaming ring, \\ A dragon head appears, from out whose mouth Two flaming flakes of fire, stretch East and West. EDOL And see, from forth the body of the star, Seven smaller blazing streams, directly point On this affrighted kingdom. (IV.v.2-9) ${ }^{73}$}

The shape of the blazing star is portrayed in detail. The blazing star presumably enters through a trap-door although its stage direction marks it to 'appear' leaving us with other possibilities open. The spectacle of the blazing star was a popular one at the outdoor playhouses. Rowley was aware of the dangers of fireworks in indoor playhouses. The Birth of Merlin was first performed at the Curtain and the title of the play claims that The Birth of Merlin was 'several times Acted with great Applause'.

In terms of collaboration and authorship, Robb argues that the play 'probably has a difficult history of revision, abridgement, and augmentation'. ${ }^{74}$ The title-prescription

\footnotetext{
${ }^{70}$ Ibid., p. 172

${ }^{71}$ E. H. C. Oliphant, The Plays of Beaumont and Fletcher: An Attempt to Determine Their Respective Shares of Others (New Haven: Yale University, 1927), p. 406.

${ }^{72}$ William Shakespeare, The Shakespeare Apocrypha, ed. by C. F. Tucker Brooke (Oxford: Oxford University Press, 1908), p. xlvi.

${ }^{73}$ Joanna Udall, A Critical, Old-Spelling Edition of The Birth of Merlin (Q 1662)

(London: The Modern Humanities Research Association, 1991), p. 171

${ }^{74}$ Dewar. M. Robb, 'The Canon of William Rowley's Plays', Modern Language
} 
claims that the play was written by both Shakespeare and Rowley. However, Campbell and Quinn deny the ascription of authorship of The Birth of Merlin to Shakespeare: 'there is nothing in the play to support the ascription to Shakespeare, and most scholars assign it to Rowley, with Thomas Middleton considered as a possible collaborator'. ${ }^{75}$ However, I assume that the name of Shakespeare might be ascribed to the title of the play only for commercial reasons as Shakespeare's name carried much weight in 1662, unlike Rowley's. According to Dominik, the play is, overall, Shakespeare-and-Rowley' ${ }^{76}$ However, he fails to mention that Shakespeare had retired to Stratford upon Avon sometime around 1613 and his career was over in the theatre. In addition to this, Rowley also cannot be seen as Shakespeare's collaborator because Rowley did not join the King's Men until 1623. ${ }^{77}$ However, Shapiro argues that 'neither the thematic nor the stylistic arguments for Shakespeare's co-authorship, detailed as they are, favour collaboration over imitation'. ${ }^{78}$ Brooke, the most recent editor of The Birth of Merlin, supports this idea and says:

There is not a single poetic passage in The Birth of Merlin, which will justify for an instant the hypothesis of Shakespeare's authorship. The disjointed nature of the plot, moreover, the foolish and immature morality of the Modestia scenes, and the repeated appeals to the cheap make-shifts of sorcery and divination, stamp it as distinctively un-Shakespearian. ${ }^{79}$

I can assume that the scene when the two flying dragons shoot fire is Rowley's own material. He was aware of the technical ability of the theatre to stage these supernatural scenes in the play. Rowley 'was an actor-manager intimately involved with the most important theatrical companies of the Jacobean age, and who in a few instances contributed to the authorship of plays that are recognized as

Review, 45 (1950), 129-141 (p. 139).

${ }^{75}$ O. J Campbell and E. G. Quinn, The Reader's Encyclopedia of Shakespeare (New York: Crowell, 1966), p. 71. Some other scholars also agree that the serious parts of the play have been written by Middleton. Howe would assign the various parts as follows: I, i, 2, Middleton. II, i, Rowley; ii, iii, Middleton. III, i, Rowley; ii, Middleton; iii, either might have written it; Ivv, Rowley; v, either;VIi, Middleton. IV, i, first 135 lines, Rowley; remainder, Middleton; ii, iii, iv, Middleton; v, Rowley. V, i, Rowley; ii, Middleton. Fred Allison Howe, 'The Authorship of "The Birth of Merlin", Modern Philology, 4 (1906), 193-205, (p 205). However, some others ascribe the play to the great poets Beaumont and Fletcher after he compared the play to Cupid's Revenge, and he concludes that Rowley may have revived the play for a revival since his name was connected with the work by the publisher. William Wells, 'The Birth of Merlin', Modern Language Review, 16 (1921), 129-137 (p. 137).

${ }^{76}$ Dominik, William Shakespeare and The Birth of Merlin, p. 10.

${ }^{77}$ Donald W. Foster, review of 'William Shakespeare and the Birth of Merlin', ed. by Mark Dominik; 'Shakespeare's Lost Play: Edmund Ironside', ed. by Eric Sams, Shakespeare Quarterly, 39 (1988), 118-123 (p. 119).

${ }^{78}$ Michael Shapiro, review of 'William Shakespeare and "The Birth of Merlin", ed. b Mark Dominik; 'Shakespeare's Romances and the Royal Family', ed. by David M. Bergeron; 'Patriarchal Structures in Shakespeare's Drama', ed. by Peter Erickson, Modern Language Review, 83 (1988), 945-947 (p. 945).

${ }^{79}$ William Shakespeare, The Shakespeare Apocrypha, ed. by C. F. Tucker Brooke (Oxford: Oxford University Press, 1908), p. xivi. masterpieces-hardly an inconsiderable achievement' ${ }^{80}$ All critics agree that Act five, scene one was written by William Rowley himself in which magic has a vital role in supporting the main characters. In other words, the comic parts of the play including the supernatural elements are assigned to Rowley only.

The entertainment in this play is centred in the battles of wit and magic which are similar to The Friar Bacon and Friar Bungay. The play also includes other dramatic devices for entertaining the audience such as a devil, fighting dragons, a blazing star, and the birth scene with its dancing 'Anticks'. The most central event in the play is that of Joan's sexual relationship with the devil which leads to the birth of the Magician Merlin. Merlin is a wonderful character throughout the play especially in his prophetic parts of the play. At the beginning of Act four, the characters enter with a Drum and then the fighting of the two dragons occurs. Regarding the dragon-fight (IV.i.2008), in the original staging the dragons were presumably represented by actors in dragon costumes and not models like that in Friar Bacon and Friar Bungay (I.1198), or firework-powered effects. ${ }^{81}$ There are two dragons: the Red dragon represents the Britons and the White the Saxons. The two dragons Red and White fight and finally the White dragon drives off the Red. The significance of colour symbolism here is that the red colour stands for the British people in their wars against the Saxons; it also symbolizes blood and fire. Again the theme of English nationalism, as in Friar Bacon and Friar Bungay, emerges here. The red dragon is used here to protect the Britons against their enemy, the Saxons. These dragon scenes portray a historical battle between the Britons and the Saxons when the Briton army under Ambrosius Aurelianus defeated the Anglo-Saxon invaders. The stage direction reads as: 'Merlin strikes his wand. Thunder and Lightning, two Dragons appear, a White and a Red, they fight a while and pause' (IV.i.208) ${ }^{82}$. The next stage direction reads as: 'Thunder: The two Dragons fight agen, and the White Dragon drives off the Red' (IV.i.2014). ${ }^{83}$ Merlin predicts to Vortiger that the white dragon will first overthrow the red one but that eventually the victory will be for the Britons:

VORTIDER The conquest is on the white Dragon part, Now Merlin faithfully expound the meaning. (IV.I.215216)

Udall argues that the dragons in The Birth of Merlin make their entrances though a trap-door ${ }^{84}$ In order to make the noise of the machinery inaudible while the dragons enter though the trap-door, the stage directions read first as:

\footnotetext{
${ }^{80}$ Dominik, William Shakespeare and The Birth of Merlin, p. 30.

${ }^{81}$ Anthony Harris, Nights' Black Agents: Witchcraft and Magic in Seventeenthcentury English Drama (Manchester: Manchester University Press, 1980), pp. 155-156.

${ }^{82}$ Udall, A Critical, Old-Spelling Edition of The Birth of Merlin (Q 1662),p. 167. ${ }^{83}$ Ibid., p.167; William Shakespeare and William Rowley, William Rowley 1585-1642?: The Birth of Merlin (1662)

${ }^{84}$ Ibid., p. 13.
} 
'Merlin strikes his wand', and the 'Thunder and Lightening' before the dragons appear (IV. i. 252-254). Lucina and the Fates also enter through a trap-door after the Devil commands them, and their appearance is preceded by thunder: 'Rise, rise to aid this birth prodigious' (III.iii.14). The Devil here is in the role of incubus and is here to help with the task of Merlin. The devil is described in the stage direction as follows: 'Enter the Devil in mans habit, richly attir'd, his feet and his head horrid' (III.i.195). The description of the Devil in this stage direction conforms to the popular tradition of stage Devils. The use of the Devil as the father of magician, Merlin, is also traditional. Rowley offers a visual comic effect by displaying the appearance of the Devil who is meant to be Merlin's father. $\mathrm{He}$ teaches Merlin and advises him on some of his supernatural power. A throne with steps would appear to be in use at I.ii.139 ${ }^{85}$, when Aurelius 'descends' to greet Artesia. ${ }^{86}$ Aurelius says: 'Most fair Artesia, see the King descends [coming down from the throne]'.

In The Birth of Merlin the defeat of a foreigner is also portrayed in the play. For instance, the Hermit's supernatural victory over the Saxon (I.i) is taken as a symbol of divine intervention by Aurelius, and of witchcraft by the Saxons. ${ }^{87}$ What I observe from this play is that Merlin and others who stand against Artesia always win. One of the popular themes in this play is the effect of lust on kings and their government. Furthermore, for example, Aurelius is bewitched (III.vi.133). After the stage direction reads '[Exeunt Aurelius, Ostorius, Octa, Artesia, Toclio, Oswold], Edwin says: 'He's sure bewitch'. Aurelius is a victim of feminine witchcraft and his death is announced by Merlin as he was looking for the peace and stability of his country:

A King more good, the glory of our Lord,

The milde, and gentle, sweet Aurelius. (IV.v.58-59)

It is also through the power of Merlin's art that the two servants of the Devil are forced to flee (i.48). The supernatural victory of the Hermit upon the Saxons, which is addressed in (I. i), have a sign of divine intervention by Aurelius, and witchcraft by the Saxons. In other words, each party has some aids from supernatural powers: the Britons have Anselme, the Hermit and the Saxons have Proximus, a magician. The Hermit could humiliate Proximus, the Saxon wizard, but his final downfall is Merlin, who says to Proximus

Hast thou such leisure to enquire my Fate,

And let thine own hang careless over thee?

Knowst thou what pendelous mischief roofs thy head,

How fatal, and how sudden?

\footnotetext{
${ }^{85}$ Udall, A Critical, Old-Spelling Edition of The Birth of Merlin (Q 1662), $\mathrm{p}$. 128.

${ }^{86}$ William J. Lawrence, Pre-Restoration Stage Studies (Cambridge: Mass., 1927), p. 319.

${ }^{87}$ Ibid., p. 55
}

\section{PROXIMUS. Pish!}

Bearded abortive, thou foretell my danger!

My lord, he trifles to delay his own.

MERLIN. No, I yield my self : and here before the King Make good thine Augury, as I shall mine.

If they fate fall not, thou hast spoke all truth,

And let my blood satisfie the Kings desires:

If thou thy self wilt write thine Epitaph,

Dispatch it quickly, there's not a minutes time

'Twixt thee and thy death

PROXIMUS. Ha, ha, ha!

[A stone falls and kills Proximus. (IV. i.217-231)

Through demonstrating his magic art, the Hermit predicts doom for Aurelius if he persists to marry Artesia and acts as a counsellor to Modestia. After the birth of Merlin, the hermit disappears and Merlin takes his place at the ruins of Vortiger's castle and displays his magical art until the end of the play. The death of Proximus is also caused by Merlin's means when a stone falls down on his head. Beside the art of magic, witchcraft is also is portrayed in the play. Rowley in The Birth of Merlin associates witches with spectacle. Lucina, Queen of the Shades, is summoned up as a supernatural midwife; the Devil calls on Lucina and the three Fates for their assistance:

\section{Enter Lucina and the three Fates}

Thanks, Hecate; hail, sister to the Gods!

There lies your way, haste with the Fates, and help,

Give quick dispatch unto her labouring throws,

To bring this mixture of infernal seed

To humane being; [Exit Fates.

And to beguile her pains, till back you come,

Anticks shall dance and Musick fill the room

[Dance DEVIL. Thanks, Queen of Shades. (III. iii, 15-

In the early modern period, the figure of the midwife or the 'wise woman' carried the stigma of witchcraft. Midwives assisted pregnant women to ensure the safety of them and their child. However, midwives were also accused of using their supernatural power to cause miscarriage and injury to women. Lucina (named after the Roman goddess of childbirth) has the role of a midwife and aids Joan when she gives birth to Merlin. However, Lucina answers to the name 'Hecate' and uses her 'Anticks,' 'dance', and 'musick,' to aid Joan in the process of delivery successfully, perhaps recalling Middleton's Hecate in The Witch who also appears with music and dances with her fellow witches. These words here Lucina utters label her as an alleged witch to the audience. The Christian church as well as criminal courts often condemned single women and healers as witches, even if they were not known as the village wise women. Wise women were considered healers, and would make up a medicine from herbs for the sick person to take, or make up a poultice to heal sores and aches and pains. Horsley argues that the evidence for the "cunning folk" or "wise women" in the sixteenth and seventeenth centuries comes from England 
and the cunning folk of English countryside were the leaders and practitioners of the people's religion as well as their folk medicine'. ${ }^{88}$ Cunning folk were also known by the name of wise-women, wise-men, conjurors and wizards. Cunning folk were mostly involved in the problems of theft, love magic, and sickness. They could also ward off evil spirits using charms, and cured those people and animals who were thought to be bewitched by witches. They also functioned as diviners to detect witches. Once people thought that were bewitched, they went to the diviners in order to suggest to them who should be accused. A number of cunning-folk were sentenced to death not because of being guilty of practicing harmful witchcraft but for magical practices such as revealing the identity of thieves or conjuring spirits.

Male witches were called warlocks or wizards, for example Merlin, the wizard of Arthurian legends. The role of the magician Merlin is to acquire knowledge and wisdom in a short time. In The Late Lancashire Witches, the witches have the power of shape-shifting, and they can turn one into cats, rabbits, dogs and horses. However, in The Birth of Merlin, the art of magic is used in aiding the army, giving birth, and the transformation of Joan's character to good before her death. A series of magical acts also occurs between the Devil, Lucina and Joan:

JOAN. Oh, help me gentle son.

MERLIN. Fear not, they shall not hurt you.

DEVIL. Relievest thou her to disobey thy father?

MERLIN. Obedience is no lesson in your school; Nature and kind to her commands my duty; The part that you begot was against kinde, So all 1 ow to you is to be unkind. (V.i.53-60)

The devil threatens Merlin thus, 'lle blast thee, slave, to death, and on this rock stick thee <as $>$ an eternal Monument', (V.i.60-62) but Merlin's power is greater and he is not afraid of the Devil as he threatens to punish him and enclose him in a rock. This contrasts with Marlowe's Doctor Faustus where Mephistopheles prevents Faustus from repenting and threatens to tear his body into thousands of pieces if he does not obey his orders. Similarly, in The Witch of Edmonton, the Devil threatens to tear Mother Sawyer into pieces if she breaks the pact they made between them. Merlin as a magician is not only doing evil acts but he also announces that Stonehenge is going to be raised for his mother as a sepulcher as well as a monument. He thinks that his mother is worthy of a blessed resting place where no acts related to black magic and evil can intrude. This is because Joan will be purged of all evil before her death. Therefore, what Merlin tries to do for his mother represents the most conspicuous act of goodness which Rowley displays in the play. It is also with the aid of Merlin's magical power that his mother's character is changed and she is not a foil anymore for Modestia and Constantia.

In sum, this paper has discussed stage directions of

\footnotetext{
${ }^{88}$ Richard A Horsley, 'Further Reflections of Witchcraft and European Folk Religion', History of Religion, 19 (1979), 71-95 (p. 78).
}

magicians, male witches and dragons in four plays. It has shown that these creatures were particularly interesting for Elizabethan and Jacobean audiences since they were visually colourful and entertaining. The stage directions in the supernatural scenes in each play were given according to the staging condition of the theatres at that time. Only Doctor Faustus has two text versions and thus different stage directions, whereas the other three plays have similar stage directions in early and modern editions.

\section{References}

[1] Barnes, Barnabe, The Devil's Charter: A tragedy Containing the Life and Death of Pope Alexander the six (London: 1607)

[2] The Devil's Charter: A tragedy Containing the Life and Death of Pope Alexander the six. As it was plaide before the kings Maiejestie, vpon Candlemasse night last by his Maiejesties Seruants. But more exactly renewed, corrected and augmented since by the Author, for the pleasure and prays of the Reader

[3] The Devil's Charter, ed. by Nick Hern (London: International Shakespeare Globe Centre, 1999)

[4] Campbell, O. J and E. G. Quinn, The Reader's Encyclopedia of Shakespeare (New York: Crowell, 1966)

[5] Clark, Stuart, Thinking with Demons: The Idea of Witchcraft in Early Modern Europe (New York: Oxford University Press, 1997)

[6] Cox, John D., 'Stage Devilry in Two King's Men Plays of 1606', Modern Language Review, 93 (1998), 934-947

[7] Dominik, Mark, William Shakespeare and The Birth of Merlin (Oregon: Alioth Press, 1991)

[8] Foster, Donald W., review of 'William Shakespeare and the Birth of Merlin', ed. by Mark Dominik; 'Shakespeare's Lost Play: Edmund Ironside', ed. by Eric Sams, Shakespeare Quarterly, 39 (1988), 118-123

[9] Greene, Robert, Friar Bacon and Friar Bungay, ed. by J. A. Lavin (London: Ernest Benn Limited, 1969)

[10] Friar Bacon and Friar Bungay, ed. Daniel Sletzer (University of Nebraska Press, 1963)

[11] Friar Bacon and Friar Bungay, ed. by Daniel Sletzer (London: Edward Arnold, 1964)

[12] Friar Bacon and Friar Bungay ([Menston]: Scolar Press, 1973)

[13] The Life and Complete Works in Prose and Verse of Robert Greene, ed. by Alexandre B. Grosart, 15 vols (New York: Russell \& Russell, 1964)

[14] The dramatic and poetical works of Robert Greene \& George Peele: with memoirs of the authors and notes, ed. by Alexander Dyce (London: Routledge, 1861)

[15] Halpern, Richard, 'Marlowe's Theatre of Night: "Doctor Faustus" and Capital', ELH, 71 (2004), 455-495

[16] Harris, Anthony, Night's Black Agents: Witchcraft and Magic in Seventeenth-century English Drama (Manchester: Manchester University Press, 1980) 
[17] Henslowe, Philip, Henslowe's Diary, ed. by A. Foakes and R. t. Rickert (Cambridge: C. U. P., 1961)

[18] Horsley, Richard A, 'Further Reflections of Witchcraft and European Folk Religion', History of Religion, 19 (1979), $71-95$

[19] Howe, Allison, 'The Authorship of "The Birth of Merlin", Modern Philology, 4 (1906), 193-205

[20] Kirschbaum, Leo, 'Mephistophilis and the Lost "Dragon", Review of English Studies, 21 (1945), 233-235

[21] Knight, Sarah, 'The Niniversity at The Bankside: Robert Greene's Friar Bacon and Friar Bungay', in The Oxford Handbook of Tudor Drama, ed. by Betteridge and Walker (Oxford: Oxford University Press, 2012), pp. 355-370

[22] Lawrence, William J., Pre-Restoration Stage Studies (Cambridge: Mass., 1927)

[23] Marlowe, Christopher, The Tragicall History of the Life and Death of Doctor Faustus (London, 1616)

[24] Christopher Marlowe: Doctor Faustus, ed. by Roma Gill, $2^{\text {nd }}$ ed. (London: A \& C Black, 1989)

[25] Marlowe's Tragical History of the Life and Death of Doctor Faustus; a conjectural reconstruction, ed. by W. W. Greg (Oxford: Clarendon Press, 1950)

[26] The Tragical History of the Life and Death of Doctor Faustus (The University of Michigan: Clarendon Press, 1950)

[27] Marlowe: Doctor Faustus, a Casebook, ed. by John Jump (London: MacMillan and Co Ltd, 1969)

[28] Christopher Marlowe: Tamburlaine, parts I and II; Doctor Faustus, A- and B-texts; The Jew of Malta; Edward II, ed. by David Bevington and Eric Rasmussen (Oxford and New York: Oxford University Press, 1998)

[29] Christopher Marlowe: Doctor Faustus, ed. by Roma Gill (London: Ernest Benn Limited, 1965)

[30] Christopher Marlowe: Dr Faustus, ed. by Roma Gill; revised with a new introduction by Rose King, $3^{\text {rd }}$ ed. (London: A \& C Black Publisher, 2008)

[31] Christopher Marlowe: Doctor Faustus, 1604 and 1616 (Menston: Scolar Press, 1970)

[32] Doctor Faustus: A- and B-texts $(1604,1616) /$ Christopher Marlowe and his collaborator and revisers, ed. by David Bevington and Eric Rasmussen (Manchester: Manchester University Press, 1993)

[33] Marlowe: Dr. Faustus, ed. by J. P. Brockbank (London: Edward Arnold, 1962)

[34] Christopher Marlowe: Doctor Faustus, ed. by Keith Walker (Edinburgh: Oliver \& Boyd, 1973)

[35] Marlowe's Doctor Faustus 1604-1616: Parallel Texts, ed. by W. W. Greg (Oxford: Clarendon Press, 1950)
[36] Christopher Marlowe: Doctor Faustus with the English Faust Book, Introduction and Notes, ed. by David Wootton (Cambridge: Hackett Publishing Company, 2005)

[37] McNeir, Waldo F. McNeir, 'Robert Greene and John of Bordeaux’, PMLA, 64 (1949), 781-801

[38] Mountford, William, The Life and Death of Doctor Faustus (1697) (London: E. Whitelock, 1697)

[39] Oliphant, E. H. C., The Plays of Beaumont and Fletcher: An Attempt to Determine Their Respective Shares of Others (New Haven: Yale University, 1927)

[40] Ornstein, Robert, 'Marlowe and God: The Tragic Theology of Dr. Faustus', PMLA, 83 (1968), 1378-1385

[41] 'The Comic Synthesis in Doctor Faustus', ELH, 3 (1955), $165-172$

[42] Palmer, Philip Mason, Robert Pattison More, and Robert T. More, Sources of the Faust Tradition ([]: Ardent Media, 1966)

[43] Robb, Dewar. M., 'The Canon of William Rowley's Plays', Modern Language Review, 45 (1950), 129-141

[44] Rosen Barbara, Witchcraft in England, 1558-1618 (New York: University of Massachusetts Press, 1991)

[45] Shakespeare William, The Shakespeare Apocrypha, ed. by C. F. Tucker Brooke (Oxford: Oxford University Press, 1908)

[46] The Shakespeare Apocrypha, ed. by C. F. Tucker Brooke (Oxford: Oxford University Press, 1908)

[47] Shakespeare, William and William Rowley, William Rowley 1585-1642?: The Birth of Merlin (1662)

[48] Shapiro, Michael, review of 'William Shakespeare and "The Birth of Merlin", ed. b Mark Dominik; 'Shakespeare's Romances and the Royal Family', ed. by David M. Bergeron; 'Patriarchal Structures in Shakespeare's Drama', ed. by Peter Erickson, Modern Language Review, 83 (1988), 945-947

[49] Simpson, Jacqueline, 'Fifty British Dragon Tales: An Analysis', Folklore, 83 (1978), 79-93

[50] Towne, Frank, 'White Magic' in Friar Bacon and Friar Bungay?', Modern Language Notes, 67 (1952), 9-13

[51] Udall, Joanna, A Critical, Old-Spelling Edition of The Birth of Merlin ( $Q$ 1662) (London: The Modern Humanities Research Association, 1991)

[52] Wells, William, 'The Birth of Merlin', Modern Language Review, 16 (1921), 129-137

[53] Werrett, Simon, Fireworks: Pyrotechnic Arts and Sciences in European History (Chicago and London: The University of Chicago Press, 2010)

[54] Wickham, Glynne, "'Exeunt to the Cave": Notes on the Staging of Marlowe's Plays', The Tulane Drama Review, 8 (1964), 184-194 